\title{
Perkinsus marinus in the pleasure oyster Crassostrea corteziensis cultivated on the southeast coast of the Gulf of California, Mexico
}

\author{
Lizeth Carolina Villanueva-Fonseca ${ }^{1}$, Manuel García-Ulloa ${ }^{1}$, Melina López-Meyer ${ }^{2}$ \\ Brenda Paulina Villanueva-Fonseca ${ }^{3}$, Juan Antonio Hernández-Sepúlveda ${ }^{4}$ \\ Norma Patricia Muñoz-Sevilla ${ }^{5}$ \& Andrés Martín Góngora-Gómez ${ }^{1}$ \\ ${ }^{1}$ Instituto Politécnico Nacional, Centro Interdisciplinario de Investigación para el Desarrollo Integral Regional \\ Unidad Sinaloa, Departamento de Acuacultura, Guasave, Sinaloa, México \\ ${ }^{2}$ Instituto Politécnico Nacional, Centro Interdisciplinario de Investigación para el Desarrollo Integral Regional \\ Unidad Sinaloa, Departamento de Biotecnología, Guasave, Sinaloa, México \\ ${ }^{3}$ Universidad Autónoma de Occidente, Unidad Guasave, Guasave, Sinaloa, México \\ ${ }^{4}$ Instituto Politécnico Nacional, Centro Interdisciplinario de Investigación para el Desarrollo Integral Regional \\ Unidad Sinaloa, Departamento de Medio Ambiente, Guasave, Sinaloa, México \\ ${ }^{5}$ Instituto Politécnico Nacional, Centro Interdisciplinario de Investigaciones y Estudios sobre Medio Ambiente \\ y Desarrollo, Ciudad de México, México \\ Corresponding author: Andrés Martín Góngora-Gómez (gogam69@hotmail.com)
}

\begin{abstract}
The protozoan Perkinsus marinus has been associated with high mortality episodes of the eastern oyster Crassostrea virginica in the USA. The presence of P. marinus on the pleasure oyster Crassostrea corteziensis cultivated in two estuaries on the southeast coast of the Gulf of California was evaluated. Oysters were collected monthly (September 2016 to September 2017) and analyzed using Ray's fluid thioglycollate medium (RFTM) and polymerase chain reaction (PCR). Water parameters and oyster biometrics were also recorded. Pathogen prevalence increased over time from 0 to $100 \%$ in oysters from La Pitahaya, and from 0 to

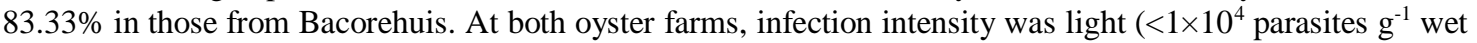
tissue), pathogen prevalence and infection intensity were correlated with oyster size and weight, and there was a strong correlation between $P$. marinus prevalence and intensity (La Pitahaya $r=0.91$; Bacorehuis $r=0.82$ ). The oysters that resulted positive for $P$. marinus by RFTM also were assayed using PCR. $P$. marinus presence was confirmed in 98.27\% (114/116) of the oysters from La Pitahaya, and 95.83\% (46/48) of those from Bacorehuis. The detection of $P$. marinus confirms that this pathogen is well established in the area with high expression during the warmer season. Despite the light infection intensity of this parasite at both sites, health surveillance of this bivalve in the region is highly advisable.
\end{abstract}

Keywords: Perkinsus marinus; Crassostrea corteziensis; pathogen; diseases; prevalence; infection intensity; Gulf of California

\section{INTRODUCTION}

Diseases of farmed mollusks cost billions of dollars each year, and the movement of exotic pathogens to new culture areas is one of the most important factors for disease dispersion (Lafferty et al., 2015). As in many countries (Soletchnick et al., 2002; Langdon et al., 2003; Taris et al., 2007), oyster production in northwestern Mexico is based on the Japanese oyster (Crassostrea gigas) (Chávez-Villalba, 2014). This bi- valve was first introduced in the 1970s on the Pacific coast of the Baja California Peninsula (Islas-Olivares, 1975), and later in the Gulf of California. Unusual episodes of high mortality in $C$. gigas associated with environmental factors (Cáceres-Martínez et al., 2018), poor culture management (Cáceres-Martínez \& Vásquez-Yeomans, 2013), and pathogens (CáceresMartínez, 2000) have been reported since 1997 (Vásquez-Yeomans et al., 2004a). Therefore, the culture of the pleasure oyster Crassostrea corteziensis, 
a native species from the Gulf of California, was suggested as an alternative to compensate for $C$. gigas losses (Chávez-Villalba et al., 2005). However, concerns about $C$. gigas mortality related, for example, to the presence of parasites have recently extended to other bivalve mollusk species in the region, including C. corteziensis (Cáceres-Martínez et al., 2016).

Different oyster species are affected by a variety of symbionts and pathogens that may cause some external and internal sings, including shell perforations (GalloGarcía et al., 2004) and damage to internal tissues (Vásquez-Yeomans, 2006; Aguirre-Macedo et al., 2007; Cáceres-Martínez et al., 2010). In other cases, high mortality at different oyster ages has been detected (Chávez-Romero et al., 2011). Among oyster parasites reported in Mexico, Vásquez-Yeomans et al. (2004b) isolated bacteria in gill tissues from oysters collected during a mortality event in Baja California; CáceresMartínez \& Vásquez-Yeomans (2013) reported the presence of a herpesvirus in C. gigas in Baja California, and Grijalva-Chon et al. (2013) detected a new type of ostreid herpes virus in C. gigas from the Gulf of California. Cáceres-Martínez et al. (2010) revealed the presence of Rickettsiales-like prokaryotes, turbellarians, encysted crustaceans, and ciliated protozoans in different tissues from $C$. corteziensis on the northcentral coast of the Mexican Pacific. They concluded that the protozoan Perkinsus marinus represented the most significant risk to oyster health. The parasite presence in the Mexican Pacific derives from $C$. virginica mobilizations from the USA and the Gulf of Mexico. Cáceres-Martínez \& Vásquez-Yeomans (2013) documented three records of P. marinus introductions in the Pacific coast: one from the Washington coast to the estuary Punta Banda, Baja California, in the 1970s; another from the transfer of oysters for commercial purposes from the Tamiahua Lagoon, Veracruz to Nayarit one decade later; and the last one by mobilization of the American oyster from Lousiana, USA, to San Jorge Bay, Sonora, to protect the oyster stock and production of the impact of Katrina hurricane, in 2005 (Cáceres-Martínez \& VásquezYeomans, 2013).

Different Perkinsus-like parasites have been reported in wild and cultivated bivalve species in and around the Gulf of California using different techniques given their presence, detection, confirmation, and infection degree. For instance, $P$. marinus was found in natural populations of $C$. corteziensis on the central coast of the Mexican Pacific (Cáceres-Martínez et al., 2008) and the mangrove oyster Saccostrea palmula along the Sinaloa coast (Cáceres-Martínez et al., 2012), as well as in the wild population of the black clam Chione fluctifraga in Kino Bay, Sonora (Enríquez-
Espinoza et al., 2015). Perkinsus sp. has been diagnosed in a natural bank of the pen shell Atrina maura in Sinaloa (Góngora-Gómez et al., 2016) and cultivated Japanese oysters along the coast of Sonora in the Gulf of California (Enríquez-Espinoza et al., 2010) and on the north-central coast of Sinaloa (VillanuevaFonseca \& Escobedo-Bonilla, 2013). Cáceres-Martínez et al. (2016) determined the prevalence and intensity of $P$. marinus in two cultured populations of $C$. corteziensis in the state of Nayarit, Mexico, from 2007 to 2014 and pointed out that no unusual mortalities were related with the presence of the parasite.

The presence of $P$. marinus in pleasure oysters farmed off the north coast of Sinaloa, Mexico, remains unknown. Assessing the possible impact of this pathogen on C. corteziensis cultivated in this state is of paramount importance. Thus, this study's objective was to evaluate $P$. marinus in $C$. corteziensis at two oyster farms on the southeast coast of the Gulf of California.

\section{MATERIALS AND METHODS}

\section{Oysters}

Crassostrea corteziensis specimens were sampled at two oyster farms located in the Bacorehuis $\left(26^{\circ} 06^{\prime}-\right.$ $\left.26^{\circ} 32^{\prime} \mathrm{N}, 109^{\circ} 01^{\prime}-109^{\circ} 20^{\prime} \mathrm{W}\right)$ and La Pitahaya $\left(25^{\circ} 21^{\prime}-\right.$ $\left.25^{\circ} 24^{\prime} \mathrm{N}, 108^{\circ} 30^{\prime}-108^{\circ} 45^{\prime} \mathrm{W}\right)$ estuaries in northern Sinaloa, Mexico. According to the farmers' information, the oyster seed was produced at the Centro de Reproducción de Especies Marinas del Estado de Sonora (CREMES) of the Instituto de Acuacultura del Estado de Sonora, O.P.D., which were certified as parasites-free. The small oysters (4.5 $\mathrm{mm}$ size range) were transported to the cultural sites and acclimated following standard procedures (Gallo-García et al., 2001). As traditionally performed in the region, oysters were cultured in a suspended long-line system, according to Villanueva-Fonseca et al. (2017). Thirty oysters were sampled monthly in both sites throughout a single culture cycle from September 2016 to September 2017 (13 months). The mean initial shell height (SH, major axis) and total weight (TW) were $4.35 \pm 0.78 \mathrm{~mm}$ and $0.01 \pm 0.004 \mathrm{~g}$. The specimens were randomly collected from several oyster trays each month and transported live in $20 \mathrm{~L}$ plastic tanks for further analysis at the Centro Interdisciplinario de Investigaciones para el Desarrollo Integral Regional (IPN-CIIDIR) Unidad Sinaloa, Guasave, Sinaloa, Mexico. At each sampling, the oyster biometrics ( $\mathrm{SH}$ and TW) and water parameters (temperature, salinity, dissolved oxygen, $\mathrm{pH}$, transparency, depth, chlorophyll$a$ concentration, total suspended solids, and particulate organic and inorganic matters) were recorded in order to assess any possible correlation with parasite preva- 
lence. The technical staff of each farm recorded survival according to their work routine.

\section{Perkinsus marinus diagnosis}

Once at the lab, oysters $\left(\mathrm{N}=30\right.$ ind month $^{-1}$ site $\left.^{-1}\right)$ were immediately processed for Perkinsus marinus diagnosis. Fouling organisms and mud were removed from each oyster using a soft brush and a stream of freshwater. Next, specimens were opened, and the soft tissue divided into two subsamples. One subsample from each oyster was incubated in Ray's Fluid Thioglycollate Medium, RFTM (Ray, 1966; OIE, 2012) with the addition of antibiotics (penicillin and streptomycin) and an antifungal (nystatin) and incubated in the dark for $7 \mathrm{~d}$ at room temperature (23$25^{\circ} \mathrm{C}$ ) to induce hypnospore formation; the other subsample was placed at $-70^{\circ} \mathrm{C}$ for confirmatory PCR analysis. Subsequently, the tissues were digested $\left(\mathrm{NaOH} 2 \mathrm{M}, 60^{\circ} \mathrm{C}\right.$ for $2-6 \mathrm{~h}$ ) and rinsed with deionized water; next, they were placed on a slide, stained with $3 \%$ Lugol's solution, and observed under light microscopy (100x) for the presence of spherical, blue, or bluish-black $P$. marinus hypnospores. Samples with a high number of hypnospores were serially diluted to reduce the total cell number to a manageable number.

The number of hypnospores per gram of oyster tissue was calculated. The effect of P. marinus in the sampled oysters was evaluated based on the infection intensity and prevalence. The infection intensity was classified as negative ( 0 hypnospores), light $\left(<1 \times 10^{4}\right.$ hypnospores $\left.\mathrm{g}^{-1}\right)$, moderate $\left(1 \times 10^{4}\right.$ to $5 \times 10^{5}$ hypnospores $\left.\mathrm{g}^{-1}\right)$, or heavy $\left(>5 \times 10^{5}\right.$ hypnospores $\left.\mathrm{g}^{-1}\right)$ (Bushek et al., 1994). The pathogen prevalence was defined as the number of infected oysters in the sample and expressed as a percentage of the total number of oysters sampled (Thrusfield, 1995).

Specimens with a positive RFTM result were subjected to PCR. Total deoxyribonucleic acid (DNA) extraction was achieved using a DNAzol ${ }^{\circledR}$ kit following the manufacturer's protocol (Molecular Research Center, Inc., Cincinnati, OH). At the same time, PCR was performed using the primers PmarITS-70F (5'CTT-TTG-YTW-GAG-WGT-TGC-GAG-ATG-3') and PmarITS-600R (5'-CGA-GTT-TGC-GAG-TACCTC-KAG-AG-3') that amplify a 509 of the ITS region of the $P$. marinus rRNA gene complex. The PCR mix was prepared as follows: $100 \mathrm{ng}$ of DNA template; $1 \times$ PCR Buffer (10 mM Tris-HCl, $\mathrm{pH} 8.5, \mathrm{KCl} 50 \mathrm{mM}$ ); $\mathrm{MgCL}_{2} 1.5 \mathrm{mM} ; 0.2 \mathrm{mM}$ of a mixture of dATP, dCTP, dGTP, and dTTP; $0.01 \mathrm{mM}$ of each primer; and $1.5 \mathrm{U}$ of proofreading Taq DNA polymerase (Bioline, Boston, MA, USA) in a final volume of $25 \mu \mathrm{L}$. Amplification conditions were: an initial denaturation step of $95^{\circ} \mathrm{C}$ for $5 \mathrm{~min}$ followed by 35 cycles of $94^{\circ} \mathrm{C}$ for $1 \mathrm{~min}, 60^{\circ} \mathrm{C}$ for $1 \mathrm{~min}$, and $72^{\circ} \mathrm{C}$ for $1 \mathrm{~min}$, and a final elongation of $72^{\circ} \mathrm{C}$ for $5 \mathrm{~min}$ (Audemard et al., 2004). Also included in the reactions were a positive control (total genomic DNA of P. marinus infected tissue from $C$. corteziensis) and negative control in which sterile water was added instead of the template. All PCR analyses were performed in triplicate. The PCR products were separated on $1.5 \%$ agarose gels, stained with ethidium bromide $\left(1 \mu \mathrm{g} \mathrm{mL} \mathrm{m}^{-1}\right)$, and visualized using ultraviolet light.

\section{Statistical analysis}

All data were tested for normality (Lilliefors test) and heteroscedasticity (Bartlett's test) to select appropriate statistical analyses. Prevalence values were arcsine transformed before analysis. The differences in the number of hypnospores per gram and the parasite prevalence in the oysters were compared between the two sites every month using a Mann-Whitney U test and a paired-sample t-test, respectively. Spearman's rank correlation was used to relate the infection intensity and prevalence data with the oyster biometrics and environmental parameters at the two oyster farms. All statistical analyses were performed using Statistica (Statsoft Inc., Tulsa, OK, USA). The significance level was set to $\alpha=0.05$ for all tests.

\section{RESULTS}

\section{Growth and mortality of oysters and environmental data}

After one year of culture, the SH and TW of Crassostrea corteziensis from the La Pitahaya and Bacorehuis oyster farms were $62.74 \pm 3.74$ and $68.82 \pm$ $6.77 \mathrm{~mm}$ and $35.09 \pm 4.94$ and $38.75 \pm 11.27 \mathrm{~g}$, respectively. The daily length and weight growth rate were $0.14 \mathrm{~mm} \mathrm{~d}^{-1}$ and $0.08 \mathrm{~g} \mathrm{~d}^{-1}$ in La Pitahaya and 0.18 $\mathrm{mm} \mathrm{d}^{-1}$ and $0.09 \mathrm{~g} \mathrm{~d}^{-1}$ in Bacorehis. The mortality was recorded during the autumn and winter seasons, from October 2016 to February 2017 at La Pitahaya and from November 2016 to January 2017 at Bacorehuis. Final survival was 64.43 and $75.56 \%$ for La Pitahaya and Bacorehuis farms, respectively. The mean water parameters for the La Pitahaya and Bacorehuis estuaries are shown in Table 1.

\section{Perkinsus marinus diagnosis}

The RFTM test shows that out of 390 oysters analyzed $116(29.74 \%)$ and $48(12.31 \%)$ from the La Pitahaya and Bacorehuis estuaries, respectively, tested positive for presumptive Perkinsus marinus hypnospores by RFTM, which showed spherical cells $(5-70 \mu \mathrm{m}$ diameter) stained black or bluish-black with Lugol's solution (Fig. 1). 
Table 1. Mean water parameters in the La Pitahaya and Bacorehuis estuaries during 13 cultivation months (September 2016-September 2017).

\begin{tabular}{lcc}
\hline & La Pitahaya & Bacorehuis \\
\hline Temperature $\left({ }^{\circ} \mathrm{C}\right)$ & $27.64 \pm 4.97$ & $27.90 \pm 4.18$ \\
Salinity & $33.61 \pm 2.18$ & $32.38 \pm 4.55$ \\
Dissolved oxygen $\left(\mathrm{mg} \mathrm{L}^{-1}\right)$ & $5.84 \pm 0.93$ & $5.49 \pm 1.98$ \\
pH & $7.03 \pm 0.84$ & $7.10 \pm 0.89$ \\
Transparency $(\mathrm{m})$ & $0.64 \pm 0.29$ & $0.53 \pm 0.32$ \\
Depth $(\mathrm{m})$ & $1.45 \pm 0.45$ & $0.86 \pm 0.30$ \\
Chlorophyll- $a\left(\mathrm{mg} \mathrm{m}^{3}\right)$ & $6.70 \pm 4.63$ & $4.41 \pm 3.35$ \\
Total suspended solids $\left(\mathrm{mg} \mathrm{L}^{-1}\right)$ & $40.71 \pm 12.68$ & $37.15 \pm 30.78$ \\
Particulate organic matter $\left(\mathrm{mg} \mathrm{L}^{-1}\right)$ & $19.63 \pm 2.38$ & $19.68 \pm 4.65$ \\
Particulate inorganic matter $\left(\mathrm{mg} \mathrm{L}^{-1}\right)$ & $29.78 \pm 10.55$ & $27.46 \pm 26.75$ \\
\hline
\end{tabular}

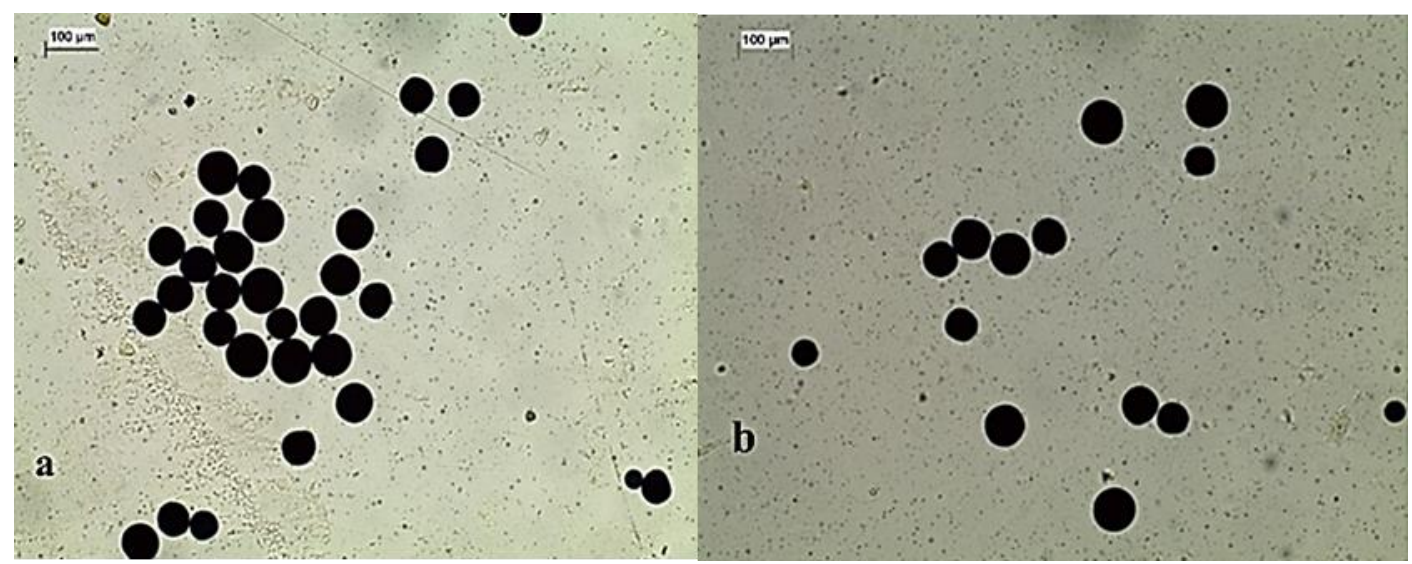

Figure 1. Detection of presumptive Perkinsus marinus hypnospores in Crassostrea corteziensis from a) La Pitahaya and b) Bacorehuis estuaries with Ray's fluid thioglycolate medium (RFTM) (100x).

Both the prevalence and the infection intensity of $P$. marinus in $C$. corteziensis at both oyster farms increased over time (Fig. 2).

For La Pitahaya, P. marinus was not detected (September-November 2016 and February 2017) or occurred with a low prevalence (December 2016, March-May 2017). Prevalence increased from June to September 2017, reaching 100\% in the last two months. For Bacorehuis, the parasite was not detected from October to December 2016 and February 2017 or occurred with a low prevalence (January, March-July 2017). Prevalence increased in August, reaching $83.33 \%$ in the last month. At the end of the culture cycle, the number of hypnospores per $g$ of wet tissue (wt) of the oysters cultivated at the La Pitahaya farm reached 9,242 hypnospores $\mathrm{g}^{-1} \mathrm{wt}$, approximately three times that found in the oysters from the Bacorehuis farm $\left(3,226\right.$ hypnospores $\left.\mathrm{g}^{-1} \mathrm{wt}\right)$. The infection intensity was light at both oyster farms $\left(<1 \times 10^{4}\right.$ parasites $\left.\mathrm{g}^{-1}\right)$. Between sites, the prevalence was similar
( $t=1.37, P=0.18$ ) but the parasite load was significantly different ( $W=8.33, P=0.0008$ ). Table 2 shows the correlations between the prevalence and intensity of infection with oyster measurements and physicochemical parameters. The infection prevalence was strongly correlated with the infection intensity ( $\mathrm{La}$ Pitahaya $r=0.91$; Bacorehuis $r=0.82$ ).

The specimens testing positive for Perkinsus by RFTM were subjected to $P$. marinus species identification by PCR analysis. At La Pitahaya and Bacorehuis, 114/116 (98.3\%) and 46/48 (95.8\%) cases were confirmed, respectively (Fig. 3).

\section{DISCUSSION}

Cáceres-Martínez et al. (2008, 2010, 2012) and Martínez-García et al. (2017) reported the occurrence of Perkinsus marinus in cultivated and wild bivalves along the north-central coast of the Mexican Pacific, suggesting a possible horizontal transmission of the pro- 

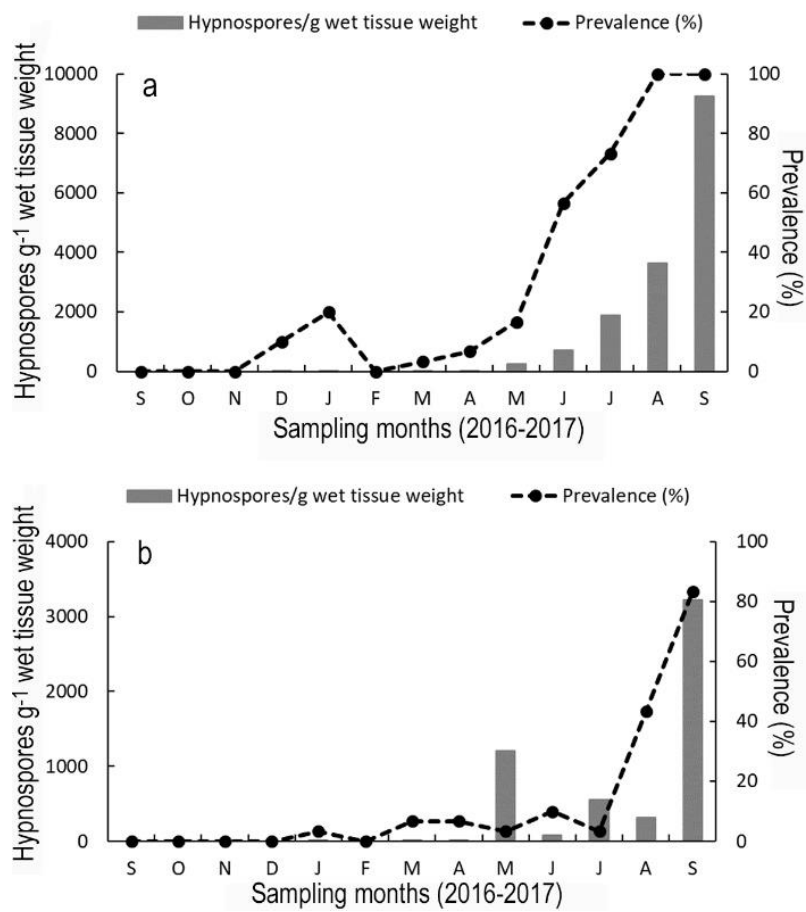

Table 2. Spearman's rank-order correlations between prevalence and intensity of Perkinsus marinus infection, with oyster measurements and environmental parameters for Crassostrea corteziensis cultivated in the La Pitahaya and Bacoreuis farms, Sinaloa, Mexico. $r$ : correlation, $P$ : p-value, SL: shell length, SH: shell height, SW: shell weight, BW: body weight, DO: dissolved oxygen. Only significant correlations $(P<0.05)$ are shown.

\begin{tabular}{lccccc}
\hline & \multicolumn{2}{c}{ La Pitahaya } & & \multicolumn{2}{c}{ Bacorehuis } \\
\cline { 2 - 3 } \cline { 5 - 6 } & $r$ & $P$ & & $r$ & $P$ \\
\hline Prevalence $v s$. SL & 0.744 & 0.0099 & & 0.794 & 0.0059 \\
Prevalence $v$ s. SH & 0.845 & 0.0034 & & 0.828 & 0.0041 \\
Prevalence $v s$ s. SW & 0.806 & 0.0052 & & 0.856 & 0.0030 \\
Prevalence $v s$. BW & 0.867 & 0.0027 & & 0.822 & 0.0044 \\
Intensity $v s$. SL & 0.810 & 0.0050 & & 0.909 & 0.0016 \\
Intensity $v s$. SH & 0.908 & 0.0017 & & 0.842 & 0.0035 \\
Intensity $v s$. SW & 0.885 & 0.0021 & & 0.893 & 0.0020 \\
Intensity $v s$. BW & 0.919 & 0.0014 & & 0.881 & 0.0023 \\
Prevalence $v s$. DO & & & & 0.725 & 0.0119 \\
Intensity $v s$. DO & & & & 0.638 & 0.0269 \\
\hline
\end{tabular}

Figure 2. Intensity (hypnospores $\mathrm{g}^{-1}$ wet tissue weight) and prevalence of the infection of Perkinsus marinus in $C$. corteziensis in a) La Pitahaya and b) Bacorehuis estuaries.

tozoan in the zone. In the present study, the protozoan P. marinus was detected in Crassostrea corteziensis from both oyster farms by the presence of characteristic round bluish-black hypnospores by RFTM assay (OIE, 2003). Specimens with positive RFTM assay results were subsequently subjected to confirmatory PCR analysis. Oyster mortality at both sites was not consistent with the prevalence throughout the culture cycle. Mortality from October 2016 to February 2017 was recorded at low or null infection; meanwhile, the infection intensity increased from May 2017 onwards, coinciding with the increase in water temperature. The present study coincided with the dynamics of Perkinsus described for Cáceres-Martínez et al. (2016), that reported an established pattern of the prevalence and intensity of Perkinsus infection in the Nayarit coast, showing low values from late autumn to early spring, while the highest values reported were in late summer and early autumn values; these fluctuations are related to the temperature and salinity of the area. However, no correlation was found between the environmental variables with prevalence and infection intensity of $P$. marinus in both localities. The absence of a direct relationship with the temperature may reflect the time required by the parasite to multiply in the host in response to changing environmental conditions (Burreson \& Ragone-Calvo, 1996). Therefore, oyster mortality cannot be attributed to the presence of presump-

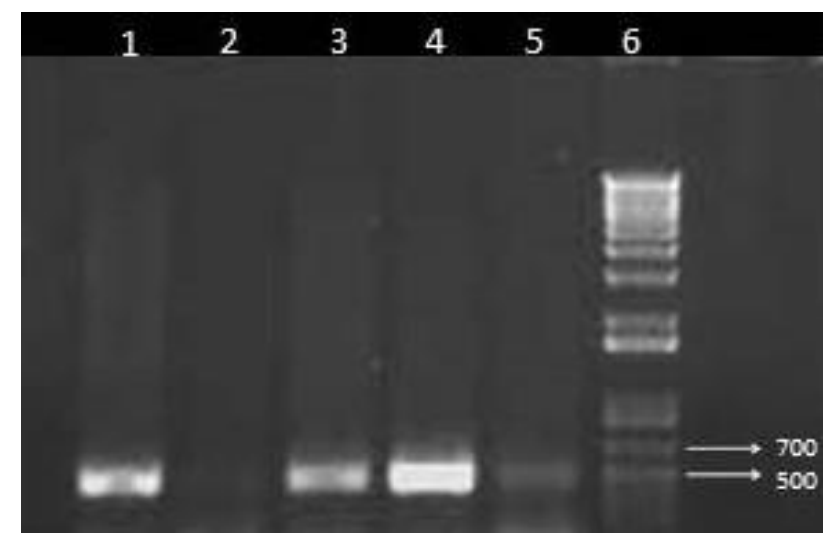

Figure 3. Agarose gel electrophoresis of PCR products. Lanes: 1) Perkinsus marinus (positive control), 2) sterile water (negative control), 3-4) fresh tissue (La Pitahaya), 5) fresh tissue (Bacorehuis), 6) molecular weight markers (1 Kb ladder).

tive hypnospores of $P$. marinus; instead, it could partially be explained by other aspects such as management and genetics.

Oyster growth and environmental parameters were similar at both sites. Only the C. corteziensis shell height and body weight were correlated with prevalence and intensity. At both locations, the infection prevalence and intensity increased with culture time, when oysters reached the highest growth values. Nevertheless, oysters were exposed to the parasite for only one year that can be a short time to favor the development of severe infections and mortalities, compared to the high mortalities of the eastern oyster $C$. virginica in the second year of cultivation registered on USA farms, attributed to $P$. 
marinus (Cáceres-Martínez \& Vásquez-Yeomans, 2013; Cáceres-Martínez et al., 2016). According to Soniat (1996), the low levels of prevalence and intensity of $P$. marinus in young oysters can be explained because their cell division rate is similar to Perkinsus. While they are adults, their growth rate decreases, and the parasite can reach higher infection intensity, which is consistent with this work, because bigger oysters $(>50 \mathrm{~mm}$ shell height) presented the highest prevalence and infection intensity of $P$. marinus. Contrary findings for other cultivated oyster species are reported by Enríquez-Espinoza et al. (2015) and da Silva et al. (2016), who found that infection rates were independent of oysters' size. According to Paytner et al. (2010) and Ehrich \& Harris (2015), larger oysters have a larger gill area that consequently leads to a higher filtration rate favoring infection through the increased ingestion of parasite cells, which could explain our results. It is also possible that larger oysters may have been infected at earlier stages, and the parasite had more time to proliferate within the host, as well as the fact that the older the oysters are, their growth rate decrease favoring the parasite proliferation; questions that deserve further research. The mean prevalence of $P$. marinus infecting $C$. corteziensis ranged from moderate (29.74\% La Pitahaya) to low (19.30\% Bacorehuis) by RFTM; the infection prevalence exceeded $80 \%$ at the end of the culture cycle. Although the MFTR staining technique does not discriminate between species of the genus Perkinsus spp., it is cheap, simple (OIE, 2012), more sensitive when compared with histology (McLaughlin \& Faisal, 1999) and the infection data collected may be counted (Auderman et al., 2008) and categorized on a scale (Mackin, 1962; Bushek et al., 1994). Also, RFTM is considered a reliable preliminary method for carrying out subsequent molecular assays (such as PCR) in processed tissues in helping to confirm parasite's species and, as in this case, to explain better the prevalence of $P$. marinus infection in $C$. corteziensis.

The results of the molecular analysis (PCR) for the positive RFTM specimens indicated parasite incidence exceeding 95\%; this is comparable with the PCR results reported by da Silva et al. (2016) in three month old Crassostrea gasar in polyculture with shrimp but higher than that reported for cultivated $C$. gigas (Villanueva-Fonseca \& Escobedo-Bonilla, 2013) and wild pen shell Atrina maura (Góngora-Gómez et al., 2016) from locations near the La Pitahaya Estuary. These differences may be due to several factors, such as the low prevalence by RFTM and the light intensity levels obtained in the present assay and the susceptibility of other species to P. marinus (Calvo et al., 1999). Moreover, the sample size used for parasite detection combined with the low infection intensities (Reece et al., 2008; Sabry et al., 2009; Dantas-Neto et al. , 2015) may have affected the output results. Finally, the different environmental conditions at each place also contribute to determining the host-parasite interaction (Villalba et al., 2004).

Of particular interest is the low infection level obtained for this oyster species on the north-central coast of Sinaloa, which coincides with the conclusions obtained by Cáceres-Martínez et al. (2012), Villanueva-Fonseca \& Escobedo-Bonilla (2013), and Góngora-Gómez et al. (2016), who reported low infection by the same protozoan in other bivalve species in the region. While the production of commercially important bivalve species has not been affected significantly by Perkinsus sp. due to their low susceptibility to this pathogen, it nonetheless represents a potential disease vector for other mollusk species in the region (Villalba et al., 2004). Therefore, sanitary measures to control the movement of bivalves from one culture site to another, and continuous monitoring of the protozoan in both cultivated and wild populations of bivalve mollusks should be implemented.

\section{CONCLUSIONS}

The infection intensity observed in this study was low. The presence of Perkinsus marinus in the north-central coast of Sinaloa confirms that this pathogen is well established in the area with high expression during the warmer season, as concluded by Cáceres-Martínez et al. (2016) for the same oyster species in natural populations of the state of Nayarit. Although no Perkinsus-related mortality has been reported for the north of the Sinaloa state, health surveillance of bivalve populations in the region is highly advisable, particularly for the native oyster Crassostrea corteziensis, which is an important component of the oyster industry.

\section{ACKNOWLEDGMENTS}

Authors thank the Instituto Politécnico Nacional for funding (SIP-IPN 20161188 and 20171303) and logistic support by COFFA and EDI. L.C. VillanuevaFonseca is a recipient of a doctoral fellowship from Instituto Politécnico Nacional (BEIFI Grant) and CONACyT. Thanks to Kristin Sullivan for the english edition of the manuscript.

\section{REFERENCES}

Aguirre-Macedo, M.L., Simá-Álvarez, R.M., RománMagaña, M.K. \& Güemez-Ricalde, J.I. 2007. Parasite survey of the eastern oyster Crassostrea virginica in coastal lagoons of the southern Gulf of Mexico. 
Journal of Aquatic Animal Health, 19: 270-279. doi: 10.1577/H06-050.1

Audemard, C., Carnegie, R.B. \& Burreson, E.M. 2008. Shellfish tissues evaluated for Perkinsus spp. using Ray's fluid thioglycolate medium culture assay can be used for downstream molecular assays. Diseases of Aquatic Organisms, 80: 235-239. doi: 10.3354/dao 01944

Audemard, C., Reece, K.S. \& Burreson, E.M. 2004. Realtime PCR for detection and quantification of the protistan parasite Perkinsus marinus in environmental waters. Applied Environmental Microbiology, 70: 6611-6618. doi: 10.1128/AEM.70.11.6611-6618.2004

Burreson, E.M. \& Ragone-Calvo, L.M. 1996. Epizootiology of Perkinsus marinus disease of oysters in Chesapeake Bay, with emphasis on data since 1985. Journal of Shellfish Research, 15: 17-34.

Bushek, D., Ford, S.E. \& Allen, S.K., 1994. Evaluation of methods using Ray's fluid thioglycolate medium for diagnosis of Perkinsus marinus infection in the eastern oyster, Crassostrea virginica. Annual Review of Fish Diseases, 4: 201-217. doi: 10.1016/0959-8030(94) 90029-9

Cáceres-Martínez, J. 2000. Resultados de los análisis patológicos efectuados a ostiones del Pacífico. Foro regional sobre la problemática en el cultivo de moluscos bivalvos en el noroeste de México, Hermosillo, Sonora.

Cáceres-Martínez, J. \& Vásquez-Yeomans, R. 2013. Enfermedades, parásitos y episodios de mortalidad de ostiones de importancia comercial en México y sus implicaciones para la producción. Ciencia Pesquera, 21: 5-48.

Cáceres-Martínez, J., Vásquez-Yeomans, R. \& PadillaLardizábal, G. 2010. Parasites of the pleasure oyster Crassostrea corteziensis cultured in Nayarit, Mexico. Journal of Aquatic Animal Health, 22: 141-151. doi: 10.1577/H09-052.1

Cáceres-Martínez, J., Madero-López, L.H., PadillaLardizábal, G. \& Vásquez-Yeomans, R. 2016. Epizootiology of Perkinsus marinus, parasite of the pleasure oyster Crassostrea corteziensis in the Pacific coast of Mexico. Journal of Invertebrate Pathology, 139:12-18. doi:10.1016/j.jip.2016.07.003

Cáceres-Martínez, J., Vásquez-Yeomans, R., Danigo, P. \& Reyes-Roel, C. 2018. Histological alterations in Pacific oysters Crassostrea gigas that survived a summer mortality event in Baja California, Mexico. Journal of Aquatic Animal Health, 30: 31-38. doi: 10.1002/aah.10006

Cáceres-Martínez, J., Vásquez-Yeomans, R., PadillaLardizábal, G. \& Del Río-Portilla, M.A. 2008. Perkinsus marinus in pleasure oyster Crassostrea corteziensis from Nayarit, Pacific coast of Mexico.
Journal of Invertebrate Pathology, 99: 66-73. doi: 10.1016/j.jip.2008.03.005

Cáceres-Martínez, J., García-Ortega, M., VásquezYeomans, R., Pineda-García, T.J., Stokes, N.A. \& Carneige, R.B. 2012. Natural and cultured populations of the mangrove oyster Saccostrea palmula from Sinaloa, Mexico, infected by Perkinsus marinus. Journal of Invertebrate Pathology, 110: 321-325. doi: 10.1016/j.jip.2012.03.019

Calvo, G.W., Luckenbach, M.W., Allen Jr., S.K. \& Burreson, E.M. 1999. Comparative field study of Crassostrea gigas (Thunberg, 1793) and Crassostrea virginica (Gmelin, 1791) in relation to salinity. Journal of Shellfish Research, 18: 465-473.

Chávez-Romero, Y.A., Cáceres-Martínez, J., VásquezYeomans, R. \& García-Ortega, A.M. 2011. Genetic characterization of ostreid herpesvirus associated with mortalities of Pacific oyster Crassostrea gigas in northwestern Mexico. 44 ${ }^{\text {rd }}$ Annual Meeting of the Western Society of Malacologists, La Paz, B.C.S., Mexico.

Chávez-Villalba, J. 2014. Cultivo de ostión Crassostrea gigas: análisis de 40 años de actividades en México. Hidrobiológica, 24: 175-190.

Chávez-Villalba, J., López-Tapia, M., Mazón-Suastegui, J. \& Robles-Mungaray, R. 2005. Growth of the oyster Crassostrea corteziensis (Hertlein, 1951) in Sonora, Mexico. Aquaculture Research, 36: 1337-344. doi: 10.1111/j.1365-2109.2005.01345.x

Da Silva, P.M., Pereira Costa, C., Bragante de Aráujo, J.P., Ramos Queiroga, F. \& Alter-Wainberg, A. 2016. Epizootiology of Perkinsus sp. in Crassostrea gasar oysters in polyculture with shrimps in northeastern Brazil. Brazilian Journal of Veterinary and Parasitology, 25: 37-45. doi: 10.1590/S1984-29612016011

Dantas-Neto, M.P., Sabry, R.C., Ferreira, L.P., Romão, L.S. \& Maggioni, R. 2015. Perkinsus sp. infecting the oyster Crassostrea rhizophorae from estuaries of the septentrional northeast, Brazil. Brazilian Journal of Biology, 75: 1030-1034. doi: 10.1590/1519-6984. 06314

Ehrich, M.K. \& Harris, L.A. 2015. A review of existing eastern oyster filtration rate models. Ecology Modelling, 297: 201-212. doi: 10.1016/j.ecolmodel. 2014.11.023

Enríquez-Espinoza, T., Grijalva-Chon, J.M., CastroLongoria, R. \& Ramos-Paredes, J. 2010. Perkinsus marinus in Crassostrea gigas in the Gulf of California. Diseases of Aquatic Organisms, 89: 269-273. doi: 10.3354/dao02199

Enríquez-Espinoza, T.L., Castro-Longoria, R., MendozaCano, F. \& Grijalva-Chon, J.M. 2015. Perkinsus marinus in Crassostrea gigas and Chione fluctifraga from Kino Bay, Sonora, Mexico. Biotecnia, 17: 10-13. 
Gallo-García, M.C., García-Ulloa, M. \& Godínez-Siordia, D.E. 2004. Evaluación de dos tratamientos en la intensidad de gusanos poliquetos asociados a las valvas del ostión Crassostrea gigas (Thunberg, 1873). Ciencia Marinas, 30: 455-464. doi: 10.7773/cm.v30 i3.283

Gallo-García, M.C., García-Ulloa, M., Godínez-Siordia, D. \& Rivera-Gómez, K. 2001. Estudio preliminar sobre el crecimiento y supervivencia del ostión del Pacífico Crassostrea gigas (Thunberg, 1873) en Barra de Navidad, Jalisco, México. Universidad y Ciencia, 17: 83-91.

Góngora-Gómez, A.M., Rubio-Zepeda, F., VillanuevaFonseca, L.C., Álvarez-Dagnino, E., Muñoz-Sevilla, N.P., Hernández-Sepúlveda, J.A. \& García-Ulloa, M. 2016. Primer registro de Perkinsus sp. (Protozoa, Apicomplexa) en el callo de hacha Atrina maura en Sinaloa, México. Revista de Biología Marina y Oceanografía, 51: 689-694. doi: 10.4067/S0718-1957 2016000300020

Grijalva-Chon, J.M., Castro-Longoria, R., RamosParedes, J., Enríquez-Espinoza, T.L. \& MendozaCano, F. 2013. Detection of a new OsHV-1 DNA strain in the healthy Pacific oyster, Crassostrea gigas Thunberg, from the Gulf of California. Journal of Fish Diseases, 36: 965-968. doi: 10.1111/jfd.12028

Islas-Olivares, R. 1975. El ostión japonés (Crassostrea gigas) en Baja California. Ciencias Marinas, 2: 58-59. doi: $10.7773 / \mathrm{cm} . v 2 \mathrm{i} 1.270$

Lafferty, K.D., Harvell, C.D., Conrad, J.M., Friedman, C.S., Kent, M.L., Kuris, A.M., Powell, E.N., Rondeau, D. \& Saksida, S.M. 2015. Infection diseases affect marine fisheries and aquaculture economics. Annual Review of Marine Sciences, 7: 471-496. doi: 10.1146/annurev-marine-010814-015646

Langdon, C., Evans, F., Jacobson, D. \& Blouin, M. 2003. Yields of cultured Pacific oyster Crassostrea gigas, Thunberg, improved after one generation of selection. Aquaculture, 220: 227-244. doi: 10.1016/s0044-8486 (02)00621-x

Mackin, J.G. 1962. Oyster disease caused by Dermocystidium marinum and other microorganisms in Louisiana. Institute for Marine Science, University of Texas, 7: 132-229.

Martínez-García, M.F., Grijalva-Chon, J.M., CastroLongoria, R., Chávez-Villalba, J.E., EnríquezEspinoza, T.L., Maeda-Martínez, A.N. \& PeñaMessina, E. 2017. OsHV-1 and notifiable protozoa in healthy Crassostrea corteziensis cultured in two distant areas of the Gulf of California. Latin American Journal of Aquatic Research, 45: 699-707. doi: 10.3856/vol45-issue4-fulltext-6

McLaughlin, S.M. \& Faisal, M. 1999. A comparison of diagnostic assays for detection of Perkinsus spp. in the softshell clam Mya arenaria. Aquaculture, 172: 197204. doi: 10.1016/S0044-8486 (98)00447-5

OIE. 2003. Manual of diagnostic tests for aquatic animals. World Organizations for Animal Health, Paris.

OIE. 2012. Manual of diagnostic tests for aquatic animals. World Health Organization. Office International des Epizooties, Paris.

Paytner, K.T., Politano, V., Lane, H.A., Allen, S.M. \& Meritt, D. 2010. Growth rates and prevalence of Perkinsus marinus prevalence in restored oyster populations in Maryland. Journal of Shellfish Research, 29: 309-317. doi: 10.2983/035.029.0205

Ray, S.M. 1966. A review of the culture method for detecting Dermocystidium marinum, with suggested modifications and precautions. Proceedings of the National Shellfish Association, 54(1): 55-69.

Reece, K.S., Dungan, C.F. \& Burreson, E.M. 2008. Molecular epizootiology of Perkinsus marinus and $P$. chesapeaki infections among wild oysters and clams in Chesapeake Bay, U.S.A. Diseases of Aquatic Organisms, 82: 237-248. doi: 10.3354/dao01997

Sabry, R.C., Rosa, R.D., Magalhães, A.R., Barracco, A.M., Gesteira, T.C. \& Silva, P.M. 2009. First report of Perkinsus sp. infecting mangrove oysters Crassostrea rizophorae from the Brazilian coast. Diseases of Aquatic Organisms, 88: 13-23. doi: 10.3354/dao02136

Soletchnik, P., Huvet, A., Le Moine, O., Razet, D., Geairon, P.H., Faury, N., Goulletquer, P.H. \& Boudry, P. 2002. A comparative field study of growth, survival, and reproduction of Crassostrea gigas, $C$. angulata, and their hybrids. Aquatic Living Resources, 15: 243250. doi: 10.1016/S0990-7440(02)01175-0

Soniat, T.M. 1996. Epizootiology of Perkinsus marinus disease of eastern oyster in the Gulf of Mexico. Journal of Shellfish Research, 15: 35-43.

Taris, N., Batista, F.M. \& Boudry, P. 2007. Evidence of response to unintentional selection for faster development and inbreeding depression in Crassostrea gigas larvae. Aquaculture, 272: 69-79. doi: 10.1016/j.aquaculture.2007.08.010

Thrusfield, M. 1995. Veterinary epidemiology, Blackwell Publishing, Iowa.

Vásquez-Yeomans, R. 2006. Agentes patógenos asociados con las mortalidades masivas en el ostión japonés Crassostrea gigas, cultivado en el Noroeste de México. Tesis de Doctorado, Centro de Investigación Científica y de Educación Superior de Ensenada, Ensenada.

Vásquez-Yeomans, R., Cáceres-Martínez, J. \& Figueras, A. 2004a. Herpes-like virus associated with eroded gills of the Pacific oyster Crassostrea gigas adults in Mexico. Journal of Shellfish Research, 23: 417-419. 
Vásquez-Yeomans, R., Cáceres-Martínez, J. \& GarcíaOrtega, A.M. 2004b. Bacterias aisladas de las branquias del ostión japonés Crassostrea gigas cultivado en Bahía Falsa, Baja California, México. Anales del Instituto de Biología Serie Zoología, 75: 237-243.

Villalba, A., Reece, K.S., Ordás, M.C., Casas, S.M. \& Figueras, A. 2004. Perkinsosis in mollusks: a review. Aquatic Living Resources, 17: 411-432. doi: 10.1051/alr:2004050

Received: 11 November 2019; Accepted: 24 January 2020
Villanueva-Fonseca, L.C. \& Escobedo-Bonilla, C.M. 2013. Prevalencia del protozoario Perkinsus sp. en un cultivo de ostión japonés Crassostrea gigas en Sinaloa, México. Latin American Journal of Aquatic Research, 41: 996-1002. doi: 103856/vol41-issue5fulltext-19

Villanueva-Fonseca, B.P., Góngora-Gómez, A.M., Muñoz-Sevilla, N.P., Domínguez-Orozco, A.L., Hernández-Sepúlveda, J.A., García-Ulloa, M. \& Ponce-Palafox, J.T. 2017. Growth and economic performance of diploid and triploid Pacific oysters Crassostrea gigas cultivated in three lagoons of the Gulf of California. Latin American Journal of Aquatic Research, 45(2): 466-480. doi: 10.3856/vol45-issue2fulltext-21 